\title{
Effects of Saururus chinensis BAILL Extract in Rats with Experimentally Chronic Constipation: An application of Clinical Pathology and Digital Image Processing
}

\author{
Min-Seok Cho ${ }^{1, *}$, Seokyoun Choi ${ }^{2, * * *}$, Gilhyun Lee ${ }^{3, * * *}$, Mi Ha Ju ${ }^{4, * *}$ and Seok-Cheol Choi ${ }^{1, \ddagger * * * *}$ \\ ${ }^{I}$ Department of Clinical Laboratory Science, Catholic University of Pusan, Busan 46252 Korea \\ ${ }^{2}$ Department of Radiological Science, Catholic University of Pusan, Busan 46252 Korea \\ ${ }^{3}$ Department of Clinical Laboratory Science, Dong Eui University, Busan 47340 Korea \\ ${ }^{4}$ Department of Pathology, Dong-A University College of Medicine, Busan 49201 Korea
}

Saururus chinensis (SC) belongs to the dicotyledonous plants, and its roots, leaves and flowers are white, so it is named three hundred and seconds. It is mainly distributed in Korea, China and Japan. In Korea, it is a native plant distributed in Jejudo and Jirisan areas. It has been known to improve blood circulation, anticarcinogenic effects and purge. However, studies of the efficacy on digestive system is few. This study was conducted to evaluate the effects of oral administered-SC extract in loperimide-induced constipation rats. The amount, weight and water content of the stools were measured. The number and type of stools in the large intestines were measured, and the amount of intestinal mucus was analyzed by serological analysis and histologic special staining. The severity of constipation in SC groups was significantly less than that in control group (non-SC rats). Digital Image processing also showed weaker inflammation on the large intestines of SC groups than that of control group (non-SC group). Especially, with increased dose dependent manner of SC extract, the amount and integrity of intestinal mucus increased. These results suggest that SC extract may prevent the symptoms of constipation.

Key Words: Saururus chinensis (SC), Loperamide, Rat, Constipation, Digital image processing

\section{서 론}

최근 생활수준의 향과 서구화된 식습관 혹은 무리한 다이어트에 의해서 성별 연령을 불문하고 많은 사람들이 변비에 의상한 배변장애로 인해 삶의 질이 떨어지고 있 다(You et al., 2010). 변비 혹은 배변장애는 의학적으로 배 변 횟수가 적거나 배변 활동이 힘든 상태를 말한다. 변비 의 의학적 진단기준은 배변 횟수가 주 2 회 이하, 변의 양
이 $35 \mathrm{~g}$ 미만, 딱딱한 변, 불완전한 배변 느낌, 배변 시 긴 장감과 항문 막힘 증세 등으로 정의한다(Park et al., 2013). 변비는 누구나 흔히 격는 위장관 증세 중 하나로 발생 원인은 저술한 요인 외에도 매우 다양하여 그 해결을 위 해 가급적 습관적 약물사용의 자제와 함께 규칙적 식사 습관, 적절한 식품섭취 및 생활양식의 변화를 통해 정상 적인 배변을 유도함을 임상으로 권유하고 있다(Lee et al., 2009). 변비의 유병률은 $16.5 \%$ 이며 치료를 위해 민간요법 을 사용하는 사람은 변비환자의 $81.5 \%$, 약국에서 약을 복

Received: October 15, 2019 / Revised: December 9, 2019 / Accepted: December 11, 2019

* Graduate student, ${ }^{* *}$ Researcher, ${ }^{* * *}$ Professor.

${ }^{\dagger}$ Corresponding author: Seok-Cheol Choi. Department of Clinical Laboratory Science, Catholic University of Pusan, 57 Olyundaero, Geumjeong-gu, Busan 46252 , Korea.

Tel: +82-51-510-0569, Fax: +82-51-510-0569, e-mail: scchoi@cup.ac.kr

(C) The Korean Society for Biomedical Laboratory Sciences. All rights reserved.

@ This is an Open Access article distributed under the terms of the Creative Commons Attribution Non-Commercial License (http://creativecommons.org/licenses/by-nc/3.0/) which permits unrestricted non-commercial use, distribution, and reproduction in any medium, provided the original work is properly cited. 
용한 경험이 있는 사람은 $91.4 \%$ 로 보고된 바 있다(Kim et al., 2013).

현재 사용되고 있는 변비 치료 또는 개선 약물은 폐쇄 형변비의 경우 60 80\%라는 높은 치료효과를 나타내고 있지만 서행성변비 혹은 장무력증에 의한 변비의 치료율 이 저조하여 효과가 검증되지 않은 민간요법으로 변비를 해결하려는 사람들이 증가하고 있는 추세이다(Cheon et al., 2007).

배변장애를 겪는 환자들에 있어서 식이요법이나 운동 등을 했음에도 개선효과를 얻지 못할 경우 2 차적으로 약 물 치료를 진행하는데 삼투압 완화제와 부피형성 완화제 의 경우 복부 팽창을 일으키고 설사 등의 문제를 야기하 고 자극성 하제를 사용할 경우에는 위장관계통의 합병증 을 유발한다고 알려져 있다. 이러한 기존 약물들의 부작 용이나 문제점을 고려해보았을 때 변비 증세 개선이나 치료에 효과가 있는 새로운 천연물질의 연구가 필요하다 고 판단된다.

본 연구에 사용된 삼백초는 quercitrin, tannin 등이 많이 함유되어 있고 특히 잎에는 $\mathrm{Fe}$ 성분이 가장 많이 있다고 알려져 있으며(Lee et al., 2000; Lee et al., 2006), 전통적으로 요도염, 전립선염, 방광염, 노동피로, 근육통, 골수염에 효 과가 있다고 있다고 알려져 있다(Lee et al., 2002). 또한 삼 백초 추출물은 MMP-2와 MMP-9의 활성을 억제하여 항 염증효과 및 항산화효과가 있다는 연구결과가 보고되고 있다(Kim and Kim, 2016). 본 실험은 이러한 삼백초의 효 능을 기반으로 하여 기초분석의학인 임상병리학적 방법 과 방사선학 분야에서 응용되고 있는 디지털영상 처리기 법(Digital Image processing)을 함께 적용하여 또 다른 관 점에서의 학문적 융복합의 가능 여부도 함께 조사해 보 았다.

\section{재료 및 방법}

\section{실험동물}

체중이 180 210 g인 6주령 Sprague-Dawle계(SD) 암컷 흰쥐를 분양 받은 후(Samtokobio Co., Korea) 7일간 사육 실의 적응기간을 거친 후 무작위로 6마리씩 4개군으로 분류하였다. 사육실 환경은 온도 $22 \pm 2^{\circ} \mathrm{C}$, 습도 $55 \sim 60 \%$ 를 유지하고 환풍기로 항상 환기시켰다. 사육실의 조명은 12 시간을 타이머로 설정하여 낮/밤(12시간/12시간)을 유지 하였다. Rat 전용 사료와 물은 매일 충분한 양을 제공하였 다. 이 연구는 부산가톨릭대학교 실험동물윤리규정에 따
라 진행하였다(심의번호: CUPAEC 2019-004).

\section{실험적 변비 유도}

Loperamide를 이용하여 변비 증상을 유도하였다. Loperamide를 생리식염수에 희석하여 사용하였으며 변비 유발 을 위해 사용된 Loperamide는 약전에 따라 변비 유도 쥐 각 마리당 하루 2회(am10:00, pm18:00) kg/0.05 mg 씩 3일 동안 경구투여 하였다. 3일간 하루 2회 Loperamide를 경구 투여 하고 PM19:00시에 각 케이지 마다 변의 양을 측정 하여 변비 증상이 유발되었음을 확인하였다.

\section{삼백초 추출액 제조}

삼백초(Saururus chinensis BAILL, 이하 SC)는 경북 영천 시 소재 농업회사법인 두손애 약초에서 구입하였다. 삼백 초를 흐르는 물에 깨끗이 씻은 후 그늘에 일주일 이상 건 조시켜 분쇄기를 이용하여 잘게 분쇄한 후 박테리아 등 의 오염 방지 및 물질의 손상을 최소화하기 위하여 동결 건조 시켰다. 동결 건조된 시료 $3 \mathrm{~g}$ 과 $70 \%$ ethanol $10 \mathrm{~mL}$ 를 $15 \mathrm{~mL}$ tube에 넣어 혼합기에서 24시간 동안 자연반응 시킨 후 2,500 rpm으로 원심분리하여 상층액만 채취하였 다. 채취된 상층액을 $42^{\circ} \mathrm{C}$ 에서 남은 에탄올 성분을 충분 히 증발시킨 후 남은 시료를 농축시켜 동결 건조하여 사 용하였다.

\section{실험의 설계}

실험용 쥐 $\mathrm{SD}$ 종을 다음과 같이 각각 실험동물군으로 분류하였다.

그룹 I : 대조군으로 생리식염수만을 경구투여한 쥐 $(\mathrm{n}=10)$

그룹 II : Loperamide로 변비를 유발하고 생리식염수를 경구투여한 실험군 $(\mathrm{n}=10)$

그룹 III: Loperamide로 변비를 유발하고 삼백초 추출물 $(200 \mathrm{mg} / \mathrm{kg})$ 을 경구투여한 실험군 $(\mathrm{n}=10)$

그룹 IV: Loperamide로 변비를 유발하고 삼백초 추출물 $(100 \mathrm{mg} / \mathrm{kg})$ 을 경구투여한 실험군 $(\mathrm{n}=10)$

\section{실험 일정}

실험은 총 5 주간 진행하였는데, 1 주일은 사육실 적응기 간, 그리고 나머지 4주간은 실제 실험기간 이었다. 실험 은 변비 유발 전(0 25일)과 유발 후(26 28일)로 나눠 진 행하였다. 유발 전과 유발 후 동물들의 대변의 개수와 수 분함량을 검사였고, 28 일차에 대변의 대장 통과시간을 검 
사하였다. 그룹 III과 그룹 IV는 Loperamide로 인한 변비 유발 전 0 일차부터 삼백초 추출물을 경구투여 하였으며, 마지막 날(28일) 동물을 희생시켰다.

\section{동물의 희생과 검체 채취}

동물의 희생: 희생 전날 사료로 제거하여 금식시켰으며, 물은 충분히 공급하였다. 복강주사를 통해 약물을 주입하 는 마취를 통해서 발생할 수 있는 장관계의 손상을 방지 하기 위해 흡입 마취를 선택하였으며 에테르를 이용한 흡 입 마취를 하였다. 마취 후 복대정맥에서 $5 \mathrm{cc}$ 이상 혈액 을 채취하여 희생을 진행하였다.

검체 채취: 본 연구는 실험동물의 맹장에서 직장까지의 장기를 적출하는데 있어서 혈액이 조직으로 방출 후 스 며드는 것을 방지하고 육안적 관찰을 위하여 복대정맥에 서 혈액을 $5 \mathrm{cc}$ 이상 채취하였다(Lee et al., 2009). 채취한 맹장에서부터 직장까지의 장기는 적출한 후 $10 \%$ formaldehyde로 고정하여 조직학적 분석 전까지 냉장보관 하 였다.

\section{분석항목 및 분석방법}

체중, 사료, 사료 섭취량 측정: 체중은 사육시설 적응이 끝난 후를 시작으로 설정하였고 희생하기 직전 체중을 최 종 무게로 측정하였다. 사료 섭취량은 변비 유발 전에는 3 일 간격으로 측정하였고 변비를 유발한 이후는 하루에 한번 측정하였다.

변의 개수, 중량 및 수분함량 측정: 각 실험군의 변은 변비 유발 전과 후를 나누어 수거했으며, 수거는 실험 시 작부터 매일 케이지 안의 변을 모두 수거하여 변의 개수 및 중량을 측정하였다. 개체별 변의 수분함량은 변을 $70^{\circ} \mathrm{C}$ 건조기에서 24 시간 건조 후 건조 전후 중량의 차를 이용 하여 수분함량을 수치화 하였다.

장 통과시간 측정: 변비 유발 3 일 후 실험동물을 12 시간 절식시킨 뒤, 장 통과 표지물질인 carmine red (Sigma, USA) $1 \mathrm{~g}$ 을 사료 $5 \mathrm{~g}$ 에 혼합하여 급여한 한 후 동물이 식이를 시작하는 것을 시작시점으로 계산하여 Carmine red에 의 해서 붉은색을 띄는 변이 조금이라도 나오면 그 시점을 종료시점으로 측정하였다.

장관 내 잔류 변 개수 측정과 형태 관찰: 장관 내 잔류
변의 개수는 실험동물을 희생한 후 맹장부터 직장까지 전체 부위를 절단하여 $10 \%$ formaldehyde 인산염완충액 (phosphate buffered saline, PBS, pH 7.4)으로 고정해서 대장 안에 남아있는 변의 크기와 개수를 육안 관찰하였다.

\section{조직병리학적 분석(대장관 내 점액질 분비효과 비교):} 맹장부터 직장까지 대장관 전체를 적출 후 $10 \%$ formaldehyde 액으로 고정하여 조직 전처리 과정을 거치고 파라 핀으로 포매하였다. 파라핀절편은 $4 \mu \mathrm{m}$ 두께로 절편을 제 작하였고, periodic acid Schiff (PAS) 특수염색을 한 후 광학 현미경으로 관찰하였다.

디지털영상 처리기법: 분석은 검출 영상처리 알고리즘을 이용하여 반자동(semi-automatic) 형식으로 계산하였고. 영 상에 존재하는 백터 형태로 존재하는 픽셀 $\mathrm{M}$ 개의 데이 터에 대하여 데이터가 속한 군집 중심과 데이터 간 거리 차이가 최소가 되도록 데이터들을 $\mathrm{N}$ 개의 군집 $\mathrm{S}=\left\{\mathrm{s}_{1}, \mathrm{~s}_{2}\right.$ $\left.\mathrm{s}_{3}, \cdots, \mathrm{s}_{\mathrm{N}}\right\}$ 군집의 수는 control 3 개, high 4 개, low 6 개, vehicle 6 개를 적용하여 계산하였다. 최적화 값으로 계산 후 픽셀 값 50 이상의 모든 픽셀의 합을 계산하여 면적을 계산하 였다(Shi et al., 2010; Singh et al., 2012).

식 1) $\mathrm{M}$ 개의 데이터 $\mathrm{X}=\left\{\mathrm{x}_{1}, \mathrm{x}_{2}, \mathrm{x}_{3}, \cdots, \mathrm{x}_{\mathrm{m}}\right\}$

식 2) $\arg \min _{r, c} \sum_{m=1}^{M} \sum_{n=1}^{N} r_{n m}\left\|X m-c_{k}\right\|^{2}$

$* C_{k}$ 는 첫번째 군집의 중심을 말한다.

디지털영상 처리기법을 조직병리학적 분석에 접목하여 점액질의 크기를 비교 분석하였다.

\section{자료분석 및 통계처리}

모든 자료는 평균 \pm 표준편차로 표시하였고, 실험군과 대조군 사이의 계는 One way-ANOVA를 사용하여 유의성 을 증명하였고, Tukey 사후검증을 하였다. 사용한 프로그 램은 Prism이며 $P<0.05$ 일 때 통계 값으로 유의한 것으로 판단하였다.

\section{결 과}

\section{체중, 사료 섭취량 측정}

실험기간 동안 각 군의 체중과 식이 섭취량은 Table 1 과 같다. 변비 유발 전(0 25일) 동안 체중증가량과 식이 섭취량은 그룹 간의 유의한 차이는 나타나지 않았다. 변 비 유발 후(26 28일) 동안 역시 체중증가량은 유의한 차 
Table 1. Effect of Saururus chinensis on body weight and food intake

\begin{tabular}{lllll}
\hline \hline & Group I & Group II & Group III & Group IV \\
\hline Body weight $(\mathrm{g})$ & & & & \\
$\quad$ Start & $210.2 \pm 4.44$ & $205.7 \pm 4.24$ & $205.1 \pm 5.12$ & $204.3 \pm 6.56$ \\
Final & $323.7 \pm 15.1$ & $312.9 \pm 12.48$ & $309.5 \pm 6.6$ & $311.5 \pm 9.8$ \\
\hline Food intake (g/day) & & & & \\
BIC & $24.79 \pm 2.03$ & $25.11 \pm 1.92$ & $26.62 \pm 1.59$ & $25.54 \pm 2.50$ \\
AIC & $26.13 \pm 1.22$ & $20.06 \pm 1.62$ & $22.73 \pm 1.48$ & $21.36 \pm 1.24$ \\
\hline
\end{tabular}

Group I, Nomal group; Group II, Loperamide induction group; Group III, Loperamide induction + oral admission of SC extract (high dose); Group IV, Loperamide induction + oral admission of SC extract (low dose)

Abbreviation: SC, Saururus chinensis BAILL; BIC, Before induce of constipation; AIC, After induce of constipation

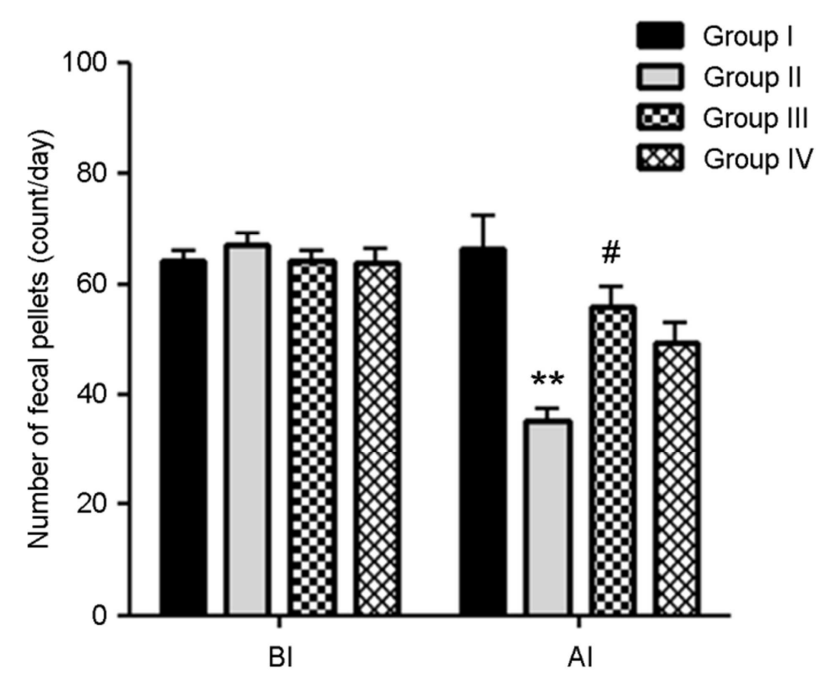

Fig. 1. Effects of Saururus chinensis (SC) on the number of fecal pellets in four groups. Group I, Nomal group; Group II, Loperamide induction group; Group III, Loperamide induction + oral admission of SC extract (high dose); Group IV, Loperamide induction + oral admission of SC extract (low dose). The numbers of fecal pellets in group II (at AI) (35.33 \pm 2.88$)$ were significantly lower than those in group I $(66.33 \pm 7.55)$ and group III $(56 \pm$ 4.66). ${ }^{* * *} P<0.01$, (compared with Group I), ${ }^{\#} P<0.05$, (compared with Group II). Abbreviation: BI, Before Induction constipation; AI, After Induction constipation; SC, Saururus chinensis BAILL.

이는 나타나지 않았지만 Loperamide를 투여한 그룹에 있 어서 사료 섭취량이 감소하는 경향이 나타났다. 변비 유 발 이후 그룹 간의 유의한 차이는 나타나지 않았으므로 Loperamide에 의한 변비가 체중, 사료 섭취량에 큰 변화 를 주지 않은 것으로 사료된다(Table 1).

\section{변의 개수, 중량}

변의 개수는 Fig. 2에서 확인하는 바와 같이 변비를 유

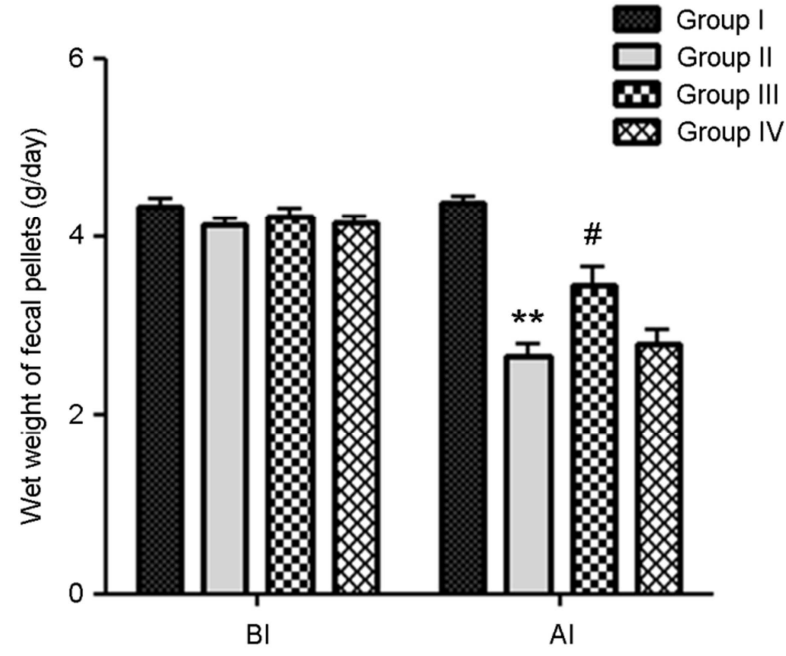

Fig. 2. Wet weight of fecal pellet in four groups. Group I, Nomal group; Group II, Loperamide induction group; Group III, Loperamide induction + oral admission of SC extract (high dose); Group IV, Loperamide induction + oral admission of SC extract (low dose). Wet weight of fecal pellet in group II (at AI) $(2.66 \pm 0.17)$ were significantly lower than those in group I $(4.4 \pm 0.06)$ and group III (3.46 \pm 0.24 ). ${ }^{* *} P<0.01$ (compare with Group I); ${ }^{\sharp} P<0.05$ (compare with Group II). Abbreviation: BI, Before Induction constipation; AI, After Induction constipation; SC, Saururus chinensis BAILL.

발하기 전 그룹 간의 차이는 없으나 Loperamide를 투여 하여 변비를 유발하였을 시 정상군(Group I)의 변 개수 $66.33 \pm 7.55$ 와 Loperamide 단독 투여 그룹(group II)의 변의 개수 $35.33 \pm 2.88$ 를 확인하면 Loperamide로 인한 변비 유 발이 잘 이루어진 것을 알 수 있다 $(P<0.01)$.

변비 유발 후 Loperamide + 삼백초 추출물 고농도 투여

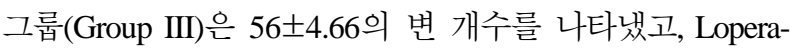
mide 단독 투여군과 비교 시 유의한 변 개수 증가를 보였 다. Loperamide + 삼백초 추출물 저농도 투여 그룹(Group 


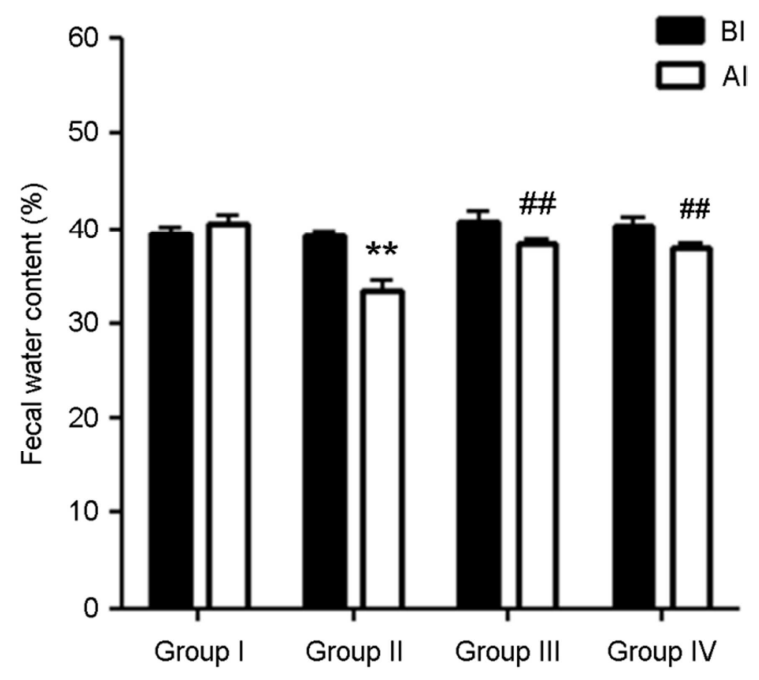

Fig. 3. Fecal water content in four groups. Group I, Nomal group; Group II, Loperamide induction group; Group III, Loperamide induction + oral admission of SC extract (high dose); Group IV, Loperamide induction + oral admission of SC extract (low dose). Fecal water content in group II (at AI) $(33.52 \%)$ were lower than those in group I (40.66), group III (38.52) and group IV (37.90\%). ${ }^{* *} P<0.01$ (compare with Group I); ${ }^{\#} P<0.01$ (compare with Group II). Abbreviation: BI, Before Induction constipation; AI, After Induction constipation; SC, Saururus chinensis BAILL.

IV)의 변 개수는 49.33 \pm 4.88 로 Loperamide 단독 투여군 비 교 시 변 개수의 증가 경향을 나타냈다 $(P<0.05)$ (Fig. 1).

변의 중량 역시 변비 유발 전은 전 그룹에서 유의한 차 이를 보이지 않았으나 변비 유발 후 변의 중량의 경우 (Fig. 3) Loperamide 단독 투여 그룹(Group II)은 2.66 \pm 0.17 으로 정상군 $(4.4 \pm 0.06)$ 과 비교하였을 시 유의한 감소를 나 타냈고, 삼백초 추출물 고농도 투여 그룹(Group III)은 3.46 \pm 0.24 로 Loperamide 단독 투여군과 비교 시 변의 중량이 증가하였다 $(P<0.05)$.

\section{변의 수분함량}

변비 유발 전 변의 수분함량은 전 그룹에서 유의한 차 를 나타내지 않았으며, 변비를 유발한 후 정상군(Group I) 과 Loperamide 단독 투여 그룹(Group II) 비교 시 Group I 에서 $40.66 \%$, Group II에서 $33.52 \%$ 변의 수분함량을 보이 는 것을 보아 Group II에서 변이 수분함량 감소를 확인하 였고, Loperamide +삼백초 추출물 고농도 투여 그룹(Group III)에서 38.52\% Loperamide + 삼백초 추출물 저농도 투여 그룹(Group IV)에서 $37.90 \%$ 를 확인한 결과, 삼백초 추출 물을 투여한 그룹들에서 수분함량의 증가를 보이고 있는 것을 나타냈다(Fig. 4) $(P<0.01)$.

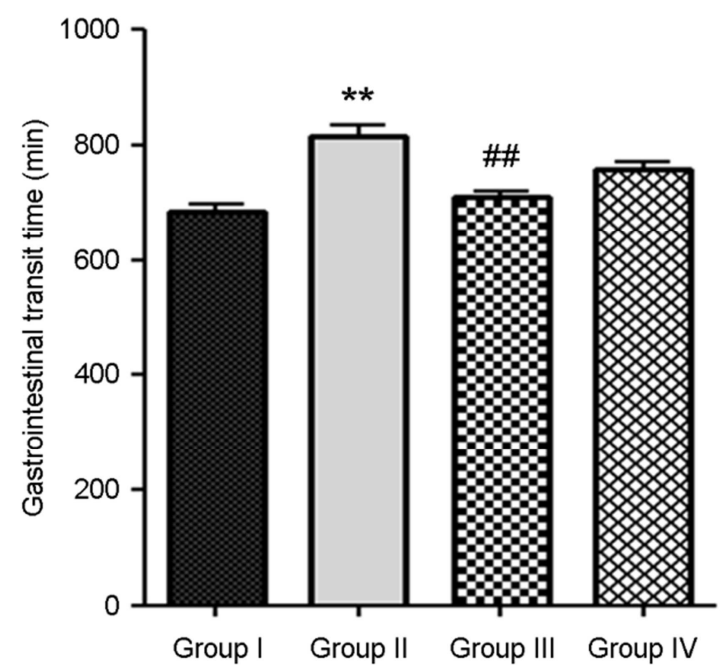

Fig. 4. Gastrointestinal transit time in four groups. Group I, Nomal group; Group II, Loperamide induction group; Group III, Loperamide induction + oral admission of SC extract (high dose); Group IV, Loperamide induction + oral admission of SC extract (low dose). Gastrointestinal transit time in groups, group II (833.33 $\pm 31.66 \mathrm{~min})$ was longer than in groups III (711.67 $\pm 55.83 \mathrm{~min})$. ${ }^{* *} P<0.01$ (compare with Group I); ${ }^{\#} P<0.01$ (compare with Group II). Abbreviation: SC, Saururus chinensis BAILL.

\section{변의 장 통과시간 측정}

변의 장 통과시간 결과는 Fig. 4로 나타냈다. Loperamide 단독 투여 그룹(Group II)의 장 통과시간은 833.33土 $31.66 \mathrm{~min}$ 으로 나타났고, 삼백초 추출물 고농도 투여 그 룹(Group III)에서는 711.67 $\pm 55.83 \mathrm{~min}$ 로 Group II와 비교 하였을 시 유의한 변의 장 통과시간 단축을 확인하였다. 삼백초 추출물을 저농도 투여한 그룹(group IV)은 750土 $59.16 \min$ 으로 측정되어 변의 장 통과시간이 단축되는 경 향을 확인하였다 $(P<0.01)$.

\section{장관 내 잔류 변 개수 측정과 형태 관찰}

실험동물을 희생하여 맹장부터 직장까지 장관 내 변 개 수와 형태를 관찰한 결과는 Fig. 6와 같다. Loperamide로 변비를 유발하지 않은 그룹(Group I)에서 변 개수는 평균 $3 \pm 1$ 개로 변이 가장 적게 관찰되었으며, Loperamide로 변 비를 유도한 그룹(Group II) 변 개수는 평균 $7.5 \pm 1.5$ 개로 확인되었다. Loperamide로 변비를 유발하고 삼백초 추출 물 고농도 투여군에서의 변 개수는 $4.8 \pm 1.4$ 개, 삼백초 저 농도 투여군은 $6.1 \pm 0.8$ 개로 삼백초 추출물의 농도가 높을 수록 장관 내 변의 개수가 적게 관찰되는 경향을 보였다. 삼백초 고농도 투여군의 장관 내 변을 육안으로 관찰하 
였을 때 변의 모양이 비교적 일정함을 가지고 있는 것을 관찰할 수 있다. 그러나 Group II와 Group IV에서는 변의 크기가 비교적 작고, 변의 모양이 일정치 않았다(Fig. 5) $(P<0.05)$.

\section{조직병리학적 대장관 내 점액질 분비효과}

$\mathrm{PAS}$ 조직 특수염색 후 현미경으로 관찰 시 정상군에 조직염색상에서는 많은 점액성 물질이 보이지만 Lopera-

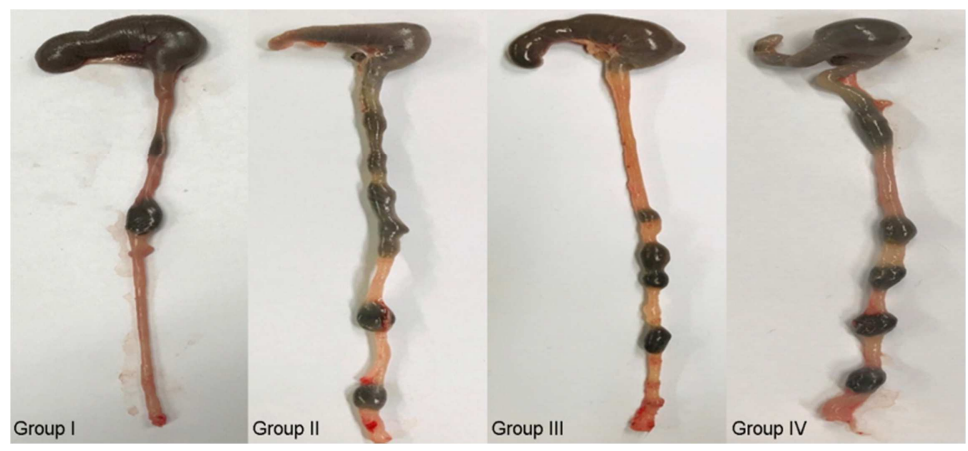

Fig. 5. Residual Fecal Measurement and Morphology of Intestines in four groups. Group I, Nomal group; Group II, Loperamide induction group; Group III, Loperamide induction + oral admission of SC extract (high dose); Group IV, Loperamide induction + oral admission of SC extract (low dose). The number of feces in the large intestine of group II (7.5 \pm 1.5$)$ was significantly higher than that of the large intestine

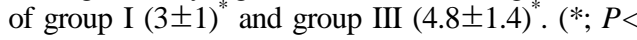
0.05 , statistical significance compared with the Group II). Abbreviation: SC, Saururus chinensis BAILL.
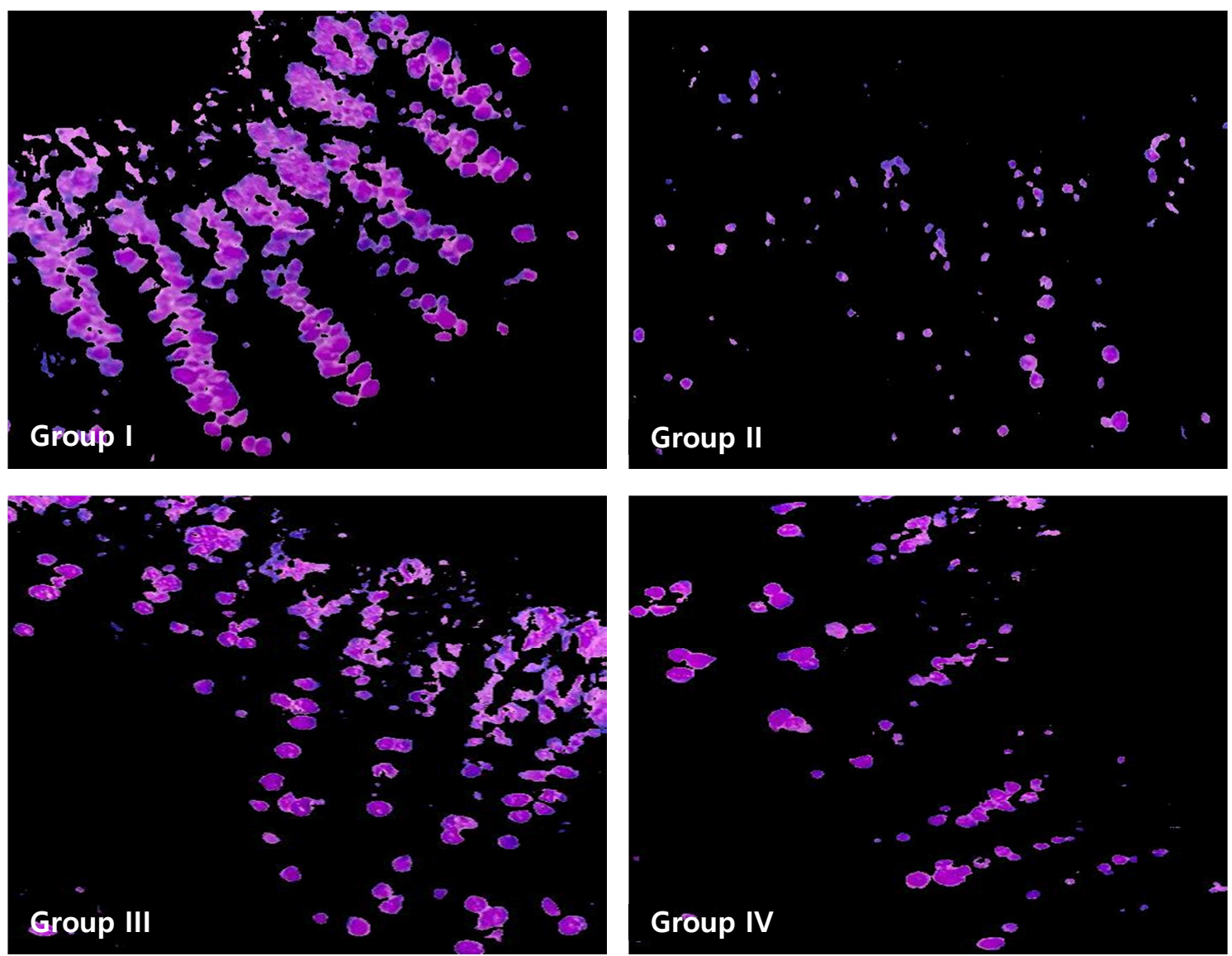

Fig. 6. Effects of the Saururus chinensis BAILL on mucous secretion capacity in loperamide induced constipation rat. Group I, Nomal group; Group II, Loperamide induction group; Group III, Loperamide induction + oral admission of SC extract (high dose); Group IV, Loperamide induction + oral admission of SC extract (low dose). Compared to Group II, mucus components were found in Groups III and Group IV more relatively. Abbreviation: SC, Saururus chinensis BAILL. 
mide 단독 투여 그룹(Group II)와 삼백초 추출물 저농도 투여 그룹(Group IV)에서는 점액성 물질이 많이 보이지 않고 삼백초 추출물 고농도 투여 그룹(Group III)에서는 비교적 많은 점액성 물질이 보이며 정상 그룹과 점액의 형태가 흡사하게 관찰되었다. 영상처리 알고리즘 기법을 이용하여 각 그룹의 점액양을 비교하였을 시 정상 그룹 (Group I) $22.04 \%$, Loperamide 단독 투여 그룹은 $2.16 \%$, 삼 백초 추출물 고농도 투여 그룹은 $12.52 \%$, 삼백초 저농도 투여 그룹은 $4.85 \%$ 로 삼백초 추출물의 농도가 높을수록 장점막의 점액 생산 및 유지에 도움이 되었다(Fig.6).

\section{고 찰}

변비가 발생하는 원인으로는 변의 수분 감소로 인하여 변이 딱딱하게 굳어 배출하기 힘든 상태를 말하며, 본 실 험에서는 지사제로 사용되며 장관의 운동성을 감소시켜 장내 수분이 흡수되는 시간을 지연시켜 변으로 다량의 수 분이 빠져나가는 설사 현상을 방지한다고 알려져 있는 Loperamide를 이용하여 변비 동물모델을 만들어 실험에 사용하였다.

Loperamide에 의해서 장내 수분 분비가 억제되어 변비 가 발생한 동물모델의 경우 변의 양, 수분함량, 배변 속 도 등을 육안적으로 파악할 수 있어 스크리닝 실험이 가 능하며, 흡사 현대인들에게 발생하는 변비와 유사한 증상 을 보이며 실험을 진행하여 변비 실험에 도움이 되는 모 델링이라 할 수 있으며 변의 양 변의 수분함량 등의 감 소를 보아 변비 증상이 발생한 것으로 간주한다.

앞서 서론에서도 언급했듯이 임상에서 변비는 장기적인 증상 개선효과가 높지 않아 새로운 약물이 필요한 상황 에 직면해 있다. 현재 우리나라의 역학적 특성과 임상 양 상과 차이점을 나타내는 북미와 유럽의 연구자료가 대부 분이므로 대한민국에 맞는 연구가 필요한 시점이다(Park et al., 2011). 현재 변비에 사용되는 약제는 Senna, Correctol, Exlax, Senokt, Gaviscon 등으로 치료에 사용되고 있으나, 높은 비용과 부작용으로 사용이 한정적인 문제점을 가지 고 있다. 특히 Tegaserod는 관상동맥을 수축시키거나 연축 시켜서 심각할 경우 심근경색을 일으킴에도 불구하고 변 비 치료에 사용되고 있는 실정이다(Kim et al., 2015). 임상 에서 역시 변비 치료의 기본원칙은 치료 초기 가급적이 면 약물 사용을 최소화하고 생활양식, 식이습관의 변화를 이용하여 정상적인 배변을 유도하는 것을 원칙으로 하고 있다(Park et al., 2011).
본 연구에 사용된 삼백초 추출물의 알려진 약리작용으 로는 풍독(風毒), 이뇨(利尿), 수종(水腫), 임질(淋疾), 간염 (肝炎), 황달(黃㾝), 폐렴(肺炎), 변독(便毒), 고혈압(高血壓) 등의 치료효과가 있는 것으로 알려져 있으며, 항산화능을 가지고 있어 노화 및 염증성 질환에 소염효과가 있는 것 으로 보고되고 있다(Byun et al., 2005; Park and Lee, 2008). 또한 삼백초는 지방세포분화에 중요한 역할을 하는 전사 인자인 PPAR $\gamma$ (peroxisome proliferator-activated receptor $\gamma$ ) 와 $\mathrm{C} / \mathrm{EBP} \alpha$ (CCAAT/enhancer binding proteins)의 발현을 억 제시켜 지방의 축적을 막는 효과를 나타내는 것으로 보 고되었다(Shin et al., 2012).

본 연구에서는 Loperamide에 의해서 체중의 변화, 식이 섭취량의 큰 변화는 발생하지 않았고 이는 기존에 변비 개선 관련 논문에서도 Loperamide에 의한 체중, 식이 섭 취량의 변화는 유의한 차이가 없다는 것과 일치된다(Jang et al., 2016).

삼백초 추출물 투여 그룹과 Loperamide 단독 투여 그룹 을 상대적으로 비교했을 때 삼백초 추출물 투여 그룹 (Group III, Group IV)에서 변의 양이 많아지고, 변의 수분 함량 역시 증가하였다. 뿐만 아니라 배변 속도 역시 단축 되어 삼백초 추출물이 변비 완화에 도움이 된다고 의심할 수 있다(Fig. 1, 2, 3, 4).

변의 양, 중량과 변의 수분함량 증가는 변비의 완화에 긍정적인 신호이고 배변 활동이 원활하게 이루어 있는 지 표로(Wang et al., 2009) 삼백초가 변비 완화에 도움이 된다 고 사료된다.

이는 삼백초 잎에서 발견되는 성분인 퀘르시트린은 혈 관 등 체내에 분포하고 있는 콜레스테롤을 효과적으로 배 출해 주고 쿠에르치트린과 플라보노이드 성분으로 인해 장관계에서 항산화 작용을 하며 발생시켜 변이 막힘없이 잘 나오도록 유도하는 것으로 사료된다(Zuo et al., 2015). 이러한 작용들에 의해서 변의 장통과시간 역시 Group II와 비교했을 시 삼백초 추출물을 복용한 Group III, Group IV 에서 시간이 단축되었으며 배변이 빨리 나오게 하는 이유 는 삼백초 잎에 존재하는 식이섬유소에 의한 영향이 큰 것으로 사료된다.

삼백초에 존재하는 식이섬유소는 장관 내 변의 양과 모 양에서도 영향을 알 수 있었다. Fig. 1에 의하면 12시간 절 식 후 control 그룹인 Group I 같은 경우 장관에 변의 양이 한 개 내외로 많지 않으나 Loperamide를 이용하여 변비를 유발시킨 Group II에서는 장관 내에 변이 다량 존재하여 뿐만 아니라 모양이 제각기 다르게 형성되어 있고, 삼백 
초 추출물 고농도를 복용시킨 Group III에서는 장관 내 변 이 Group I과 비슷하며 모양도 일정하다. 삼백초 추출물 저농도를 복용시킨 Group IV를 보면 변이 다량 관찰되고 있으나 장관 내 존재하는 변의 모양이 일정하다는 것이 Group II와의 차이점으로 보인다. 이 같은 결과는 식이섬 유소와 변비의 관계에 따른 배변작용의 선행연구에서 알 수 있듯이 삼백초 잎에 포함되어 있는 식이섬유소로 인하 여 일정한 변의 모양을 형성하는 것에 있어서 대장에 무 리가 가지 않을 만큼의 크기를 만들고 장관계에 지속적인 일정한 압력을 가하여 배변 활동에 도움이 되었던 것으로 사료된다(Lee et al., 2008).

본 연구는 삼백초가 장관계의 점액성 물질 유지에 도움 을 줄 것이라는 가설 하에 장관계의 점액물질을 확인할 수 있는 특수염색 PAS 염색을 진행하였다(Fig. 6).

변비가 발생하였을 시 장관계의 운동성이 감소하게 되 고 이에 따라서 장관계의 점액질 층의 두께 및 점액질이 감소하고, 이로 인하여 장관 안에서 변의 이동에 문제를 야기한다고 보고되었다(Cepinskas et al., 1993). 본 연구에서 대장 조직은 PAS 특수염색한 후 영상처리 알고리즘 기법 을 이용하여 조직의 특수염색된 부분만 효과적으로 나타 낸 후 특수염색 부위를 수치화 한 것으로 결과의 신뢰도 를 높일 수 있었다. 이러한 기법을 통해 점액물질을 관찰 한 결과 Group II에 비하여 Group III에서 점액물질의 개선 이 나타났으나 Group IV에서는 점액물질이 크게 개선되 지 않아 삼백초 추출물 고농도에서 점액물질의 개선이 나 타났다. 삼백초에 다량으로 들어 있다고 알려져 있는 탄 닌은 강력한 항산화 능력을 가지고 있으며 항균작용 항알 러지 작용, 고지혈증 억제작용 등의 효과를 낸다고 알려 져 있으며 본 연구에서 장관계의 점액 성분 개선의 결과 는 플라보노이드 성분의 일종인 탄닌(Tannin) 성분으로 인 한 혈액순환 개선으로 인한 장관계의 운동성 증진으로 점 액 성분이 개선 및 유지되었을 것이라고 예측한다(Hwang, 2005).

본 연구의 결과를 종합해보면 삼백초 추출물은 Loperamide으로 인하여 발생된 변비 증상에 있어서 치료효과를 보였으며, 농도가 높은 삼백초 추출물이 더욱 효과적으로 변비 증상 완화에 도움이 되었다. 이러한 결과들을 통해 삼백초 추출물은 새로운 변비 완화제로 역할을 할 수 있 을 것으로 사료된다.

\section{ACKNOWLEDGEMENT}

이 연구는 부산가톨릭대학교의 학술연구기금을 지원받
아 수행된 연구임.

\section{CONFLICT OF INTEREST}

No potential conflict of interest relevant to this article was reported.

\section{REFERENCES}

Byun HK, Shin YW, Kim EI, Kim SM, Lee JE, Yoo DY. Effect of Saururi Herba Seu Rhizoma on anti-inflammatory properties in RAW264.7 cell Line and murine models of inflammation. The Journal of Oriental Obstetric and Gynecology. 2005. 18: 51-71.

Cepinskas G, Specian RD, Kvietys PR. Adaptive cytoprotection in the small intestine: role of mucus. American Journal of Physiology-Gastrointestinal and Liver Physiology. 1993. 264: G921-G927.

Cheon JH, Yoon IJ, Myung SJ, Byeon JS, Ko JE, Jung KW, Kim BJ, Kwon SH, Do MY, Kim DH, Ye BD. Use of constipation remedies not prescribed by physician-a study of patients at a constipation clinic. Kor J Neurogastroenterol Motil. 2007. 13: 45-52.

Hwang EK. The Effect of Supplementary Feeding of Tannic acid on Growth and Hematological Changes in Rats Fed High Fat Diet. Journal of Veterinary Clinics. 2005. 22: 108-113.

Jang JH, Jung HK, Sim MO, An BK, Kim MS, Kang BM, Cho JH, Bean CG, Kim SC, Jung WS. Effect of Dendrobium speciosum Var. Aqueous Extract on Loperamide-Induced Constipation in Rats. Korean Journal of Medicinal Crop Science. 2016. 24: 1-6.

Kim JH, Kim EJ. Effect of Anti-oxidant, Anti-inflammatory and Anti-invasive of PMA-induced Matrix Metalloproteinase (MMP-2) and MMP-9 Activities of Water Extract and Solvent Fractions of Saururus chinensis. Journal of Life Science. 2016. 26: 584-591.

Kim DH, Myung SJ, Yang DH, Yoon IJ, Seo SY, Ku HS, Yoon SM, Kim KJ, Ye BD, Byeon JS, Yang SK, Kim JH. Characteristics of Korean patients with constipation who visited a tertiary referral center. The Korean Journal of Medicine. 2013. 84: 49 $-61$.

Kim JE, Park SH, Kwak MH, Go J, Koh EK, Song SH, Sung JE, Lee HS, Hong JT, Hwang DY. Characterization of changes in global genes expression in the distal colon of loperamideinduced constipation SD rats in response to the laxative effects 
of Liriope platyphylla. PloS One. 2015. 10: e0129664.

Lee E, Haa K, Yook JM, Jin MH, Seo CS, Son KH, Chang HW. Anti-asthmatic activity of an ethanol extract from Saururus chinensis. Biological and Pharmaceutical Bulletin. 2006. 29: 211-215.

Lee IS, Lee SO, Kim HS. Preparation and quality characteristics of yogurt added with Saururus chinensis (Lour.) Bail. Journal of the Korean Society of Food Science and Nutrition. 2002. 31: 411-416.

Lee JH, Um YR, Shim KS, Jeon WK, Lee JH, Ma JY. Acute Toxicity Studyon Fermented Ssanghwa-tang Extractsin Mice. Korean J Orient Int Med. 2009. 30: 780-787.

Lee JJ, Lee YM, Jung SK, Kim KY, Lee MY. Effects of dietary mulberry leaf on loperamide-induced constipation in rats. Korean Journal of Food Preservation. 2008. 15: 280-287.

Lee KA, Kim HJ, Yoon HS. Constipation prevalence and lifestyle factors affecting constipation of high school students in Gimhae area. J Korean Diet Assoc. 2009. 15: 419.

Lee ST, Park JM, Lee HK, Kim MB, Cho JS, Heo JS. Component Comparison in Different Growth Stages and Organs of Saururus chinensis B (AILL). Korean Journal of Medicinal Crop Science. 2000. 8: 312-318.

Park CS, Park KS, Kim ML, Kong HJ, Yang KM. Effects of medicinal enzyme powder on intestinal mobility, lipid level, and blood parameters of loperamide-induced constipation in rats. Korean Society of Life Science. 2013. 23: 228-236.

Park DJ, Lee JC. A Study on the Antioxidative and Depigmentation Activities of the Ethanol Extract of Saururus Herba1. Kor J Herbology. 2008. 23: 193-202.

Park MI, Shin JE, Myung SJ, Huh KC, Choi CH, Jung S, Choi MG. Guidelines for the treatment of constipation. The Korean Journal of Gastroenterology. 2011. 57: 100-114.
Shi N, Liu X, Guan Y. Research on k-means Clustering Algorithm: An Improved k-means Clustering Algorithm. 2010 Third International Symposium on Intelligent Information Technology and Security Informatics. 2010. 63-67.

Singh TR, Roy S, Singh OI, Sinam T, Singh K. A New Local Adaptive Thresholding Technique in Binarization, International Journal of Computer Science Issues. 2012. 8: 271-277.

Shin OS, Shin HY, Lee KH, Kim GY, Kim KH, Park JK, Ahn JI, Song KY. Inhibition of Adipogenesis in 3T3-L1 Adipocytes with Ethanol Extracts of Saururus chinensis. Korean Society for Biotechnology and Bioengineering Journal. 2012. 27: 381 -386 .

Wang XW, Liu HF, Xu M, Chen G, He JT, Wang GA, Teng XC, Fang DC. Proteomic analysis of down-regulated proteins in colonic mucosa of chronic slow transit constipation rats. Journal of Medical Colleges of PLA. 2009. 24: 136-141.

You JS, Park JY, Chang KJ. Correlation among dietary habits score, life stress score and health-related quality of life (HRQL) score for female college students with functional constipation. Korean Journal of Nutrition. 2010. 43: 620-627.

Zuo YM, Xu YL, Zhang ZL, Liu DH, Cai MT. Chemical Constituents from Saururus chinensis. Journal of Chinese Medicinal Materials. 2015. 38: 2538-2540.

https://doi.org/10.15616/BSL.2019.25.4.339

Cite this article as: Cho MS, Choi S, Lee G, Ju MH, Choi SC. Effects of Saururus chinensis BAILL Extract in Rats with Experimentally Chronic Constipation: An application of Clinical Pathology and Digital Image Processing. Biomedical Science Letters. 2019. 25: 339347. 